\title{
MOEDAS E CIVILIZAÇŌES Do ouro do Sudão à prata da América $\left({ }^{*}\right)$
}

O mecanismo do comércio no Mediterrâneo no século XVI, no conjunto, parece ser de grande simplicidade. A leste, a balança de comércio é sempre regularmente deficitária: eis o que orienta todos os tráficos. Esstando o comércio em māos dos ocidentais, êstes são obrigados a exportar para o Levante consideráveis quan¿idades de prata amoedada. Precisam portanto procurá-la continuamente. Grave, mas nāo problema novo. Assim foi, mais ou menos, durante quase tôda a Antiguidade e a Idade Média. Sustentou-se mesmo, por muito tempo, que o Império Romano havia sido esgotado afinal por esta hemorragia de metal precioso, em benefício do Oriente e do Extremo Oriente. Em todo o caso, para limitar o deficit, houve constantes esforços no sentido de se encontrar mercadorias capazes de substituirem a moeda. Em vez de metais preciosos, sempre tāo raros e tão difíceis de se obter, os países cristāos da Alta Idade Média chegaram a exportar escravos para os mercados do Oriente. Depois disso, tendo a Cristandade se tornado senhora dos mares, o desenvolvimento de suas indústrias - principalmente as téxteis - forneceu-lhe uma verdadeira moeda suplementar' da qual fêz ela uso em larga eșcala.

Era uma das artes, um dos segredos de Veneza, ainda no século XVII, saber muitas vêzes obter, nos bazares de Alepo ou do Cairo, especiarias, a pimenta, a sêda, o algodão ou pós, tão úteis ao seu comércio ou à sua indústria, contra mercadorias: tecidos, vidrilhos, espelhos, ao invés do pagamento em moeda. Para que serviam os agentes que a Serenísima mantinha no Levante? Eram êles que vendiam ao sabor das ocasiões - que davam a baratto como se dizia entẫo - os estoques de mercadorias que as matrizes de Veneza lhes confiavam. Essas práticas estavam ainda em uso no século XVII: vêmo-las muito bem descritas entāo, na cor-

(*). - Tradução da Lic. Emília Nogueira autorizada pela revista Annales. Fconomies-Sociétés-Civilisations. (1.0 ano, 11.0 1, 1946) e pela Editôra Librairie Armand Colin. Este artigo foi também publicado pelo jornal "O Estado de São Paulo" e merece nova publicação não só pelo fato do seu autor ter sido professor da Faculdade de Filosofia, Ciencias e Letras da nossa Universidade, como também porque o assunto 6 de grande interêsse para a nossa História e relaciona-se com os outros dois artigos anteriores a este. A Revista de Historia, por isso, resolveu estampá-lo de novo (E. SIMóES DE r'AULA). 
respondência dos cônsules venezianos da Síria. Mas outro testemunho frisará ainda melhor a dificuldade que tinha o comércio ocidental em pagar em dinheiro à vista, os preciosos produtos do Levante. Um documento ragusano de 1573 nos indica que em Alexandria do Egito, o juro do dinheiro era tāo elevado que os mercadores judeus concediam empréstimos usurários aos cristāos em dificuldades, à taxa de 36 a $48 \%$ ao ano. As colônias mercantis dos cristāos no Oriente estāo portanto freqüentemente em dificuldades de tesouraria. Será um desastre, no verdadeiro sentido da palavra, para as velhas casas venezianas da Síria, o fato de, no último têrço do século, aparecerem em massa, nos mercados do Levante, compradores franceses, depois inglêses e flamengos (o que vale dizer holandeses e zeelandeses), os quais farāo suas compras mediante dinheiro à vista, sem aguardar a oportunidade de trocas favoráveis por mercadorias. Isso provoca lògicamente uma alta de preços e uma crise brusca, à moda antiga, do comércio veneziano.

Mas era preciso obter em qualquer parte êsse indispensável dinheiro. Os franceses tiravam-no da Espanha ou da Itália; os inglêses - informa-nos Hakluyt — obtinham-no também na Itália. Gênova, Livorno, Veneza, na regiāo média do mar, sāo assim para seus próprios comerciantes e para os que traficam em seus portos, fornecedores de espécies amoedadas. Os inventários de Raguisa indicam, durante todo o século XVI, reembôlso de dinheiro proveniente de Veneza. Pequenas fontes, evidentemente em relaçāo à enorme fonte sevilhana. Porque é esta que de longe alimenta a circulação mediterrẩnea. Mas seu papel no Mediterrâneo e é éste um dos pontos que desejariamos reter - é em sua plenitude, muito mais tardio do que poderia fazer crer a cronologia das grandes descobertas. A prata, o metal branco da América, nāo chegou imediatamente em grandes quantidades aos países do mar Interior.

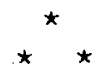

Antes do século XVI, êste mar interior, por sua vida econômica, tivera acesso a múltiplas minas de ouro e de prata, freqüentemente de pequena importância do ponto de vista absoluto, e em geral, incapazes de prosperar por muito tempo. Assim, certas minas de ouro dos Alpes, da Sardenha, da Criméia ou da Velha Sérvia; assim as minas de prata do Erz Gebirge ou do Tirol, especialmente as de Schwaz, que no século XV seriam a origem direta do poderio dos Függer e de outros comerciantes-banqueiros de Augsburgo. A atividade das minas de prata da Europa Central foi singularmente estimulada no século XV (1451) pela descoberta de novos processos de fusāo, que permitiram separar os minérios 
de prata dos minérios de cobre; mas o problema que assim se apresenta, mau grado seu interêsse, fica à margem de nossa pesquisa.

$\mathrm{Na}$ realidade, para o Mediterrâneo, a contribuiçāo regular, necessária a suas despesas habituais a leste, veio de alhures. Veio do ouro providencial do Sudāo. Ao que eu saiba, até o presente, sòmente Jaime Cortezão lhe assinalou, não tanto a importância há muito reconhecida, mas o valor no que concerne ao mecanismo geral da vida mediterrânea, ou melhor, o lugar no circuito geral dessa vida mediterrânea até às portas de saída do Oriente. Porque há uma ligação -e êste artigo pretende fixar-lhe a intensidade e a estreiteza - há uma ligaçāo que nāo foi absolutamente percebida, que nāo foi suficientemente notada, entre o prestigioso comércio do Levante e os transportes de ouro em pó do Sudão até as cidades e portos da África do Norte. Foi essa uma das oportunidades do Ocidente Latino se tornar, a partir dos séculos XII e XIII, senhor.das rotas marítimas entre a África e o Levante, e de poder, em conseqüência mesmo dêsse domínio, forçar as portas da Âfrica do Norte até entāo aferrolhadas.

Sabe-se que o ouro em pó do Sudāo constitui de longa data - sem dúvida desde o século X - ao lado dos escravos negros, o maior elemento do tráfico transaariano de retôrno. $O$ que nem sempre se vê tāo bem é que êste ouro, durante séculos, foi uma das armas decisivas do Islāo ocidental, isto é da Espanha e da África do Norte muçulmana de destinos tāo estreitamente ligados. No século $X$, a Andaluzia urbana e ativa instala-se na margem sul do estreito de Gibraltar, em Ceuta. Ela entra assim em relações econômicas, mais intimas que nunca, com os paises moghrebinos. Uma vida nova anima a Pequena África, onde se fundavam cidades como Argel e Oran, onde prosperavam centros mais antigos como Tunes e Bougie. Ora, nos séculos X e XI o ouro sudanês chega a África e por intermédio da África até a Espanha. A numismática e a história aí estão para nos informar sôbre aquêles reinos muçulmanos da Espanha, de tāo brilhante civilizaçāo. Êles nos sāo mostrados como incapazes de se defender depois do século $\mathrm{X}$ dos implacáveis estados cristāos do Norte e preferindo pagar-lhes tributos em lugar de padecer as regulares devastações de seus raids de cavalaria. Mas observemos isso de mais perto: nāo é essa uma soluçāo de ricos e de bem providos? Em todo o caso, esta riqueza sudanesa, filtrada através das rotas africanas, desembocava, ainda nos séculos XII e XIII naqueles paises do Islāo ocidental, unidos, bem ou mal, duas vêzes naquelas grandes e efêmeras construções politicas dos almorávidas e dos almóadas. A fontes da época almóada (em geral dos séculos XII e XIII) sāo concordantes: assinalam uma riqueza de metais preciosos de belos dinares de ouro, sucessivamente exportados por intermédio dos comerciantes, para o mundo inteiro e sem dúvida até ao Levante. 
Porque atrás dessa prosperidade do Islāo ocidental há - repitâmo-lo - a vida geral do Mediterrâneo.

E no século XIII que o Moghreb começa a se fragmentar em tantos Estados quantos suas cidades mercantis. Fato muito mais importante é que entāo, todos êsses Estados se abrem ao comércio cada vez mais ativo e mais indiscreto dos comerciantes cristāos. É êsse o grande acontecimento da vida do Moghreb, qualquer que seja a opiniāo da história geral, acontecimento êsse que pela sua repercussāo além de seus limites transborda largamente. O Moghreb é já, a partir do século XII, de maneira evidente, a mina de ouro sem a qual a atividade mediterrânea, notadamente o rico e poderoso comércio do Levante, se teria paralisado, ou pelo menos comprometido. Esse papel de motor, êle o desempenhá, de maneira mais decisiva ainda, no século XV. Desenvolve-se entāo, nos futuros Estados bárbaros, uma encarniçada, continuada, multiforme invasāo crista de comerciantes e também de mercenários, pois êsses Estados, aos quais a grande história nāo se refere absolutamente: os de Fez, de Marrocos, melhor ainda os dos wahabitas de Tlemcem, "a cidade dos comerciantes honestos", ou o dos hafsidas de Tunes - recrutavam soldados nos paises pobres e talvez já demasiado populosos da Cristandade.

Para os comerciantes, como para aquêles outros aventureiros, o fim era sempre o mesmo: o acesso ao precioso metal, seja alugando-se como no caso dos mercenários, seja trocando mercadorias as mais diversas: tecidos, e outras, por moedas ou ouro em pó. Os tratados comerciais assinados pelos cristāos com os "reis" da África do Norte constituem um livro completo: assim o atesta a clássica coletânea de Mas-Latrie publicada em 1866, coletânea muito rica e no entanto incompleta como verificam os eruditos todos os dias. Sôbre esta vasta arremetida, sôbre essa invasāo, a um tempo catalā, marselhesa, genovesa e mesmo ragusana, os arquivos da Europa contêm grande número de documentos inéditos. Nessas cidades mercantis, os cristāos (à maneira de suas colônias levantinas), têm seus bairros com múltiplos privilégios e franquias e também, lá como alhures, seus consulados. Em 1573, quando Dom Joāo da Áustria se instala em Tunes, seus soldados encontram na cidade cisternas outrora construidas pelos genoveses em sua antiga feitoria.

Tôdas as mercadorias que a Europa podia fornecer ou revender afluiam portanto, às ruas comerciais das cidades norte-africanas. Disso resultou um amplo desenvolvimento urbano do Norte da África. Tôdas essas cidades fizeram ruir os antigos quadros políticos. Independentes, de fato, elas fazem freqüentemente pensar 
nas repúblicas italianas do século XIII. É o caso de Oran, de Tlemcem, de Tunes, de Tripoli, e foi, antes da catástrofe de 1415, o caso de uma grande cidade - Ceuta. Mas notêmo-lo bem, essas cidades crescem em desacôrdo com a regiāo que as circunda. São um produto da economia mundial e daí sua secreta fragilidade. Não sāo, por isso, mesmo brilhantes na época. Como já se disse, elas ligam à história do Moghreb (ou melhor à sua própria história) os longínquos destinos das cidades e dos reinos do grande anel do Niger, para além do Saará. E ligam-se à tôda história do Mediterrâneo. $\mathrm{Na}$ Cristandade, nas bordas do mar, ninguém lhes ignora a existência. Sua reputaçāo de riqueza sobreviverá mesmo à sua prosperidade. Quando os espanhóis se apossaram de Trípoli em 1511, tiveram a impressāo que se apoderavam de uma cidade de ouro e levaram tempo para se desenganar. E, em 1573, ainda, (quando já não era possível aí nenhuma ilusāo) Dom Joāo d'Áustria, instalado em Tunes e desejoso de aí permanecer, imaginava (sem dúvida baseando-se en velhos documentos hafsidas) que a cidade recebesse, todos os anos, preciosos carregamentos de ouro em pó do "Tivar". Naquela data (1573) era grande a falta do ouro. De fato, desde as últimas décadas do século XV, o ouro do Sudāo nāo chega mais, pelos menos em quantidade tão considerável, às cidades da África do Norte. Isto quer dizer que no momento em que se inicia a segunda geração dos homens da Renascença, o Mediterrâneo se vê bruscamente privado de uma parte importante de seu abastecimento de ouro - e portanto, de um elemento motor indispensável à sua vida econômica. Repentinamente, a prosperidade local da Africa do Norte desaba como um castelo de cartas. Quem narrará a súbita desolaçāo de suas cidade? Essa miséria tão sensivel desde os primeiros anos do século XVI que se faz vivamente sentir, mesmo através das páginas de um livro tão frio como o de Leāo o Africano? Orı, fât extsanho: os historiadores parecem nāo ter prestado a minima atençāo até o presente, à esta crise geral da economia comercial do Mediterrâneo, ou mesmo a esta crise local da Africa do Norte. Em sua velha e clássica História Ernesto Mercier fala mesmo em "feudalizaçāo" do mundo que estuda e essa palavra mal escolhicia revela sem dúvida que o mal-estar da África do Norte, o desmoronamento das autoridades constituidas năo lhe escaparam. Mas quem já nos mostrou o Mediterrâneo em dificuldade monetária e comercial? E sobretudo, quem, tendo notado o efeito, remontou até às causas? Quem indagou o que bem pode ter ocorrido para além do Moghreb, nas profundezas do continente negro?

$\mathrm{O}$ que aconteceu? Nada. Nada mais que um pequenino, insignificante fato, do qual ninguém quis, até hoje, ver as repercussões na vida do Mediterrâneo - e, portanto, em tôda a economia, em tôda a história da Europa. Nada mais que isto: em 1460, os descobridores portuguêses atingem as proximidades do gôlfo da Gui-, 
né - 1460, o mesmo ano em que morria o grande promotor dos descobrimentos: o infante Dom Henrique, o navegador. Dez anos depois, o gôlfo é reconhecido até às ilhas de Fernando Pó, em seu extremo oriental.

Os portuguêses atingem o gôlfo da Guiné. E sem dúvida, a exploraçāo comercial das regióes interiores não começa imediatamente. Entretanto, já em 1482, erige-se São Jorge da Mina, ao mesmo tempo feitoria e fortaleza, e logo mais funcionará a Casa da Mina, central reguladora do comércio da Guiné. Por aí se processa uma verdadeira "captura" econômica dos tráficos saarianos, uma inflexāo e uma mudança de sentido. Os portuguêses se apresentam na Costa de Mina com tecidos, "hambels", grossas e rús-. ticas mantas do Alemtejo e bacias de cobre fornecidas pelo comércio de Antuérpia; e até mesmo com artigos mais preciosos ainda, como trigo e cavalos marroquinos. Com isso obtém, em troca, escravos negros e ouro em pó. Acontecimento capital, acontecimento de repercussāo mundial — os portuguêses desviam em seu proveito senāo a totalidade (Tlemcem, na época dos turcos cunhará moedas de ouro até o fim do século XVI) ao menos uma grande parte do metal precioso produzido pelos faiscadores sudaneses. Conseguemno introduzindo nos Estados e nas tribos indígenas, entre o gôlfo e a bacia do Niger, seus mercadores, agentes politicos e aventureiros, descobridores de rotas e iniciadores de tráfico, cujo papel é imenso: um século mais tarde uma crônica das ilhas do Cabo Verde assinalava ainda o papel dêsses pioneiros.

Eis pois, o ouro sudanês desviado para o Atlântico. Irá êle de lá, tomar o caminho da Europa e do Mediterrâneo? Se isso se der, nada mudou enfim para a economia européia, após naturais transtornos iniciais. Tanto faz para a Europa que o ouro que ela necessita no Levante lhe chegue às māos por intermédio dos moghrebinos ou dos portuguêses. Nesse caso, a história que reconstituimos nāo ultrapassará as proporções da anedota.

De fato, durante algumas décadas, foi quase isso que sucedeu. O ouro sudanês chegava a Lisboa - e com êle outros produtos de importância, também tirados das costas da Guiné, tal como, para só falar dela, essa falsa pimenta — a malagueta, a qual, por seu baixo preço, faria concorrência por muito tempo, na praça de Antuérpia, à verdadeira pimenta "das ilhas". Mas os navegadores portuguêses nāo cessavam de progredir para o sul. Em 1488 dobravam o Cabo da Boa Esperança com Bartolomeu Dias. Em 1498 Pedro Álvares. Cabral aî chegava também para negociar; em 1502-1503, a segunda viagem de Vasco da Gama se realizava com uma gran- 
de frota mercante. Sùbitamente, um mundo inteiro de negócios e de transações se revelava à imaginaçāo e à cobiça portuguêsa.

Desde entāo, muda-se o quadro. A princípio, os navios árabes carregados de pimenta e de especiarias, se deixavam fàcilmente capturar pelos lusitanos. Quando tais pilhagens nāo foram mais possiveis, foi preciso que êles se munissem de dinheiro para adquirir pimenta, especiarias e pérolas das Índias. Êsse dinheiro fôra encontrado, ou melhor, êsse ouro, pois que se trata do ouro sudanês. $\mathrm{E}$ eis como, em vez de dar vida ao tráfico mediterrâneo, êle toma o rumo dos paises novos. Eis como êle é, em larga medida, subtraído ao antigo tráfico do Mediterrâneo, por aquela poderosa derivaçāo para o Extremo Oriente.

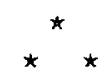

Evidentemente o mundo mediterrâneo reagitu contra essa crise. Foi êsse o eminente papel dos genoveses. Mais tarde, quando se tornou conveniente lutar pela pimenta e pelas especiarias, a defesa das posições antigas foi feita por Veneza e pelos sudaneses do Egito. Mas o primeiro abalo no monopólio e no equilibrio do Mediterrâneo veio muito anteriormente, do oeste, e a propósito do ouro sudanês. $\mathrm{O}$ mérito de Gênova, se mérito há, é o de ter, sózinha, procurado entāo uma soluçāo anti-portuguêsa. Sāo os' genoveses, nāo - esqueçamos, que, em 1470, participaram da defesa de Arzila contra os portuguêses; sobretudo, foram os genoveses que, desde meados do século XV, penetrando até Sidjilmâssa e Tuat, no interior das rotas transaarianas, tentaram sobrepujar os portuguêses empenhados nas rotas marítimas. Tudo isso inütilmente, aliás, Não se évitou de maneira alguma uma crise geral da prosperidade mediterrânea. E como tud̆o se entroza. como o ouro nāo é apenas a fôrça motriz da economia, mas, de tôdas as atividades sociais e da própria civilização (entenda-se' em nosso país, e segundo nossas tradições e nossa mentalidade de ocidentais), essa crise acarretou muitas outras conseqüências além das pròpriamente econômicas. De passagem indicaremos apenas uma, minúscula.

O que a escassez de metal amarelo comprometeu, foi em última análise, o esplendor da primeira Renascença, inseparável do vigor e da riqueza das cidades e das burguesias, produtoras do grande comércio mediterrâneo. Certamente o Mediterrâneo pôde, então, se voltar para uma Europa em pleno progresso técnico, em pleno desenvolvimento da atividade mineira. Mas, em que medida isto pôde compensar aquilo? E igualmente, qual o papel das perturbações econômicas na vasta crise das querras da Itália? Quantas questões que até hoje ninguém formulou e que uma história cônscia dos seus deveres deveria formular! Em todo caso, há um fato, fato fora de dúvida e que parece ajustar-se à nossas interpretaçóes: hou- 
ve a preocupaçāo de cunhar moedas de prata por tôda a Europa, especialmente na Europa central, e depois na Itália. Moedas de prata: êsse substitutivo, êste "erzatz" do ouro.

Crise do ouro, mais tarde, crise das especiarias e da pimenta, ambas serüo golpes terríveis, senāo delinitivos na economia mediterrânea. Ambas em última análise, serāo superadas. É bem verdade que as galés venezianas nāo puderam carregar nenhum saco de pimenta ou de especiarias em 1504, no cais de Alexandria; os próprios comerciantes alemāes, habituados ao Fondaco dei Tedeschi, tiveram que se dirigir, entāo, para suas compras, a Francfort e Antuérpia. Mas a crise aqudissima no início do século, foi de curta duraçāo. Perseguido, constrangido, maltratado, o comércio árabe do Oceano indico, mesmo assim conseguiu se manter, e, tornou-se a ver nos cais de Tripoli e Alexandria, pimenta e especiarias em quantidade. Impossibilidade de fechar o Oceano Indico aos navios árabes, devido as facilidades (nāo gratuitas) concedidas pelas autoridades portuguêsas a êsse antigo comércio? Ou seria a qualidade superior das mercadorias transportades pelos velhos caminhos do Levante - nāo tendo a pimenta que se vendia em Veneza sofrido as lentas deteriorações que ao longo de interminável viagem marítima, deveria sofrer a mercadoria portuguêsa, comprada alhures, no ponto de partida, por agentes geralmente menos espertos que os mercadores árabes? Acrescentemos ainda a politica d $\approx$ altos preços, praticada pelos portuguêses e pelos negociantes, senhores em Antuérpia do comércio da pimenta, política essa que deve ter contribuido bastante para salvar a situaçāo comprometida do comércio do Levante. Pouco importa aquí. Para nós, o essencial é que o comércio do Levante se manteve no extremo Mediterrâneo e em condições idênticas às do passado: a leste do mar permanece uma porta de saída obrigatória para os metais preciosos. Como foi isso possivel? Quando conseguiu o mundo mediterrâneo superar a crise metálica que sofria?

Fode-se dizer com segurança: foi quando a prata da América veio substituir o ouro sudanês deficiente. Foi quando na Espanha, em Sevilha, encontraram os mediterrânicos o metal branco, que salvou seu comércio. Mas te-lo-iam encontrado imediatamente?

As primeiras remessas de metais preciosos, ouro e prata (pois houve remessas de ouro americano até as alturas de 1550), chegam a Espanha no ínicio mesmo do século. Mas só assumem plena importância a partir de 1550 mais ou menos. Desde entāo, as particias de metal branco nāo cessam de aumentar, no decorrer do século, de maneira quase regular, atingindo seu máximo de 1580 
a 1640, durante o grande periodo imperialista da história da Espanha.

A atraçāo de Sevilha - onde se estabeleceu em 1513 a Casa de Coniratación - foi desde logo enorme. Entre os mais ativos comerciantes da grande cidade figuraram, desde o início, italianos de tôdas as cidades mercantis da peninsula, principalmente genoveses. $\hat{E}$ pois de presumir que, desde logo, o metal branco espanhol deve ter entrado, licitamente ou nāo, na circulaçāo européia. Evidentemente, não se poderia dizer em que proporções. $\mathrm{O}$ movimento dos comuneros de inspiraçāo xenófoba, se erguera violentamente contra a exportaçāo de metal precioso em benefício do estrangeiro. Ās Côrtes agiram sempre nesse sentido. Carlos V, ao menos até os meados dêsse século, procurou nāo contrariar ềsse grande movimento da opiniāo pública em Castela. Por outro lado, se os genoveses (porque é principalmente dêles que se trata) financiaram o desenvolvimento de Sevilha no comêço do século, se êles contribuiram poderosamente para o desenvolvimento da metrópole do negócio americano, organizado por um sistema de trocas, de empréstimos de dinheiro e de comércio a longa distância (através do oceano) e, consequientemente de longa duraçāo êles, os genoveses, nāo participaram imediatamente, da mesma forma, nos empréstimos à Corôa, únicas operações financeiras, que poderiam permitir que se tirasse o metal, em grande quantidade, de uma Espanha terrivelmente tolhida. De fato, os grandes empréstimos genoveses a Carlos $\mathrm{V}$, nāo começaram antes dos meados do século. Sòmente no reinado de Felipe II, depois da primeira bancarrota espanhola, é que êles substituirāo os empréstimos dos Függer e de outros banqueiros da Alta Alemanha. Acrescentemos também que foi só depois de 1552 que o govêrno de Carlos, deixou sair da Espanha grandes somas de prata amoedada. Tudo isso nos leva a pensar que houve certo atraso nas chegadas maciças de metal precioso ao Mediterrâneo.

Tanto mais que a prata espanhola, quando sai aos jorros da Espanha - e relativamente fácil é acompanhá-la em suas viagens pela Europa - nāo toma o caminho direto do Mediterrâneo: até 1560-1570, saincio da Espanha, ela seque a rota marítima de Laredo ou de um dos portos vizinhos da costa cantábrica até Antuérpia. Entre essas duas cidades corre um rio de prata de extrema importância para a vida econômica de tôdà a Europa, ainda que nāo se possa traçar, com segurança, os múltiplos meandros de seu curso para além de Antuérpia. Mas a existência desta corrente-mestra de Laredo a Antuérpia é de capital importância. Todos os contratos, todos os asientos estabelecidos entre os mercadores e o Rei Católico, forneczriam, se preciso, indicações confirmando essa importância. Regularmente, os senhores da Espanha remetem a Laredo quantidades de prata, em troca dos adiantamentos que lhes sāo f́eitos sôbre as praças do norte, quase sempre em Antuérpia, ou 
algumas poucas vêzes, e por somas muito menores, em praças como Milão e Nápoles. Assim o provam dois asientos de 1557, que se poderiam tomar como exemplo. Êles foram estabelecidos após a primeira bancarrota do Estado espanhol, em maio de 1558, entre Felipe II de um lado, e dois banqueiros genoveses, Nicollo Grimaldi e Constantino Gentile, de outro. Sabemos também que os Függer, que na Espanha eram arrendatários das minas de mercúrio de Almaden, das minas de prata de Guadalcanar e dos territórios das Ordens (os Maestrazgos) encontravam facilidades para. tirar a prata da Espanha através de Portugual, por intermédio de negociantes judeus interessados no comércio das Índias portuguê.sas. Êstes, particularmente desejosos de obter numerário, ofereciam em compensação, letras sôbre Antuérpia. Imâginemos, pois, ao lado dessa grande corrente oficial, un movimento considerável de prata e de capitais da Peninsula Ibérica, pelo Atlântico, até o grande centro transformador de Antuérpia.

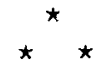

Mas, a partir de 1568 , a luta econômica e politica entre Felipe II e a Inglaterra degenera em guerra maritima. Era muito tentador, era muito fácil, para os navios inglêses, na Mancha ou no Mar do Norte, à passagem das grandes naus de Biscaia, apossarse das zabras que transportavam, para o Mar do Norte, lās espanholas, e, em massas de cinqüienta a duzentos mil ducados e mais, o precioso metal branco da América. Pode-se seguir, dia por dia, com a ajuda das cartas dos embaixadores espanhóis em Londres ou da correspondência minuciosa do duque de Alba nos PaísesBaixos, os incidentes desta luta, entrecortada de negociações e de ameaças e que, apesar dos desejos e das ordens formais de Felipe II, nāo chegou a levar à verdadeira guerra. As zaóras biscainhas eram também freqüentemente chamadas à fala, conduzidas a portos inglêses e deslastradas de sua preciosa carga. Notemos que se o Estado inglês, que até entāo emprestava capitais na praça de Antuérpia, se decidiu, após advertências, conselhos e talvez manobras de Thomas Gresham, seu agente junto aos negociantes antuerpienses a viver do crédito de seus próprios comerciantes, êle tomou primeiro suas precauções: a prata das naves nunca será devolvida. Aliás nāo é êsse abandôno, sinal precursor da decadência de Antuérpia? A pirataria inglêsa havia dado o golpe decisivo na grande navegaçāo biscainha, a qual declina quase completamente após o malôgro da tentativa marítima de Pero Menendez de Avilez, em setembro de 1574. Em Burgos, os documentos do Consulado indicam uma paralizaçắo dos negócios no último terço do século. Após Burgos, as feiras de Medina del Campo perdem, depois de 1575 (que é também o ano da segunda bancarrota espanhola) tôda a 
significaçāo internacional. Vale dizer que se acha entāo ameaçada essa antena estendida da Espanha aos Países-Baixos - todo êsse largo e poderoso avanço da Península até os mares do Norte, que desempenharam um imenso papel na história da grandeza da Espanha.

Um período da finança imperial espanhola estava concluido - um periodo também da econômia do mundo. Outrossim, se o governo inglês não vem mais beber na espantosa fonte que até entāo havia sido a bôlsa antuerpiense, se se limita, aqui e ali, a pequenos empréstimos ou a magras remessas de dinheiro para Bremen ou Hamburgo, é porque, por sua intervençāo e pela extensāo da guerra protestante aos mares do norte e a todo o Atlântico, das bordas da Europa às bordas da América, tudo se acha comprometido nesse sistema de circulação dos metais preciosos. Em seu tradicional ponto de chegada, em Antuérpia, os dias de esplendor passaram definitivamente. Nāo é mais uma cidade em tôda sua vitalidade, é uma cidade já meio arruinada, que será destruida pelo saque de 1576. Do mesmo modo, cessa nessa época a espantosa prosperidade de Liēo, ligada, como no-lo indicam os textos, nāo tanto ao Mediterrâneo, mas ao centro antuerpiense, do qual, sob muitos aspectos, foi uma escala ligada também - certos documentos o afirmam - ao comércio clandestino da prata, através dos $\mathrm{Pi}$ rineus ou por intermédio de certos portos, como Ruāo.

Seria de surpreender se esta crise nāo tivesse para a Espanha consequiencias no plano imperial. Desde antes da grande luta se ter travado entre o mundo protestante e o império hispânico, êste último se viu em parte separado dos Países-Baixos, pelo menos no que concerne a rota oceânica. Impossivel daí por diante - mil testemunhos o dizem - fazer passar por ali, a prata, com a facilidade de outrora. Cêrca de 1578, recorre-se mesmo a um gesto desesperado: fazer passar de Gênova aos Faíses-Baixos, homens de confiança, levando cosidas em suas vestes, as preciosas peças de moeda.

Em 1575, imediatamente após a segunda bancarrota, o trajeto é tāo pouco seguro, que, dispondo Felipe II, de três a quatro milhões de ducados em metal amoedado, na Peninsula, nenhum comerciante quis correr o risco de fazê-los vir por mar até os PaísesBaixos, e um empréstimo obtido dos Függer, com transferência para Lisboa, nāo impedirá que se produza a catástrofe há muito prevista: a "bolchevização" do exército espanhol dos Países-Baixos (como diz Carlos Pereyra), sua fragmentaçāo em soviets, em repúblicas de soldados saqueadores, obrigados e felizes de viver às expensas do habitante local. Nāo era êsse um dêsses abalos dos quais é difícil se refazer? Perdendo a livre utilização dos caminhos maritimos que levaram ao norte, a Espanha estava privada de um dos grandes trunfos da guerra - dessa guerra pelo domínio da Europa e do mundo. Desde essa época, a Espanha condenou-se a uma 
guerra particularmente custosa, de tal maneira se tornara para ela oneroso e dificil transportar a prata ou conduzir soldados.

Em todo caso - e é o que interessa à nossa pesquisa, - a ruptura da rota atlântica da prata espanhola na Europa iria valorizar progressivamente uma outra rota de distribuiçāo, uma rota supletiva mediterrânea, a maior parte das vêzes a rota maritima de Barcelona a Gênova. Ela ganha importância nos anos 15701575.

O papel que a principio haviam desempenhado as zabras biscainhas, na distribuiçāo européia do metal branco, passa desde então às galeras do Rei Católico. Os comboios de galeras da costa da Espanha aos portos da Itália levam em seu bojo pesadas caixas de moedas cunhadas com a marca da Espanha. Viagens de resto, sem incidentes, nunca perturbadas pelos corsários, nem sempre assinaladas, por outro lado, nos documentos das séries políticas. Não se poderia pois, dizer com certeza quando essas remessas começaram. Para isso seriam necessários muito longos e bem sucedidos inquéritos. Também não se poderia estabelecer, mesmo com os textos a māo, o volume ou mesmo a regularidade - muito provável - dêsse tráfico. Porque se a prata entra na Espanha, com muita disciplina, quase exclusivamente pela grande porta de Sevilha, para sair, nunca conheceu uma via exclusiva. E, aqui, mais que nunca, é necessário levar em conta saidas secretas, os cem caminhos da fraude; mas um fato parece fora de contestaçāo: essas remessas por via mediterrânea tornam-se evidentes à história depois dos anos de 1570-1575. Até entāo, através de numerosos documentos só sāo mencionadas pequenas remessas. Por exemplo, em 1568, uma remessa de prata ao duque da Toscana em pagamento do sôldo que - Rei Católico devia pelas galeras toscanas que lhe foram alugadas: remessa difícil aliás, epílogo de múltiplas diligências, prova suplementar da dificuldade que havia nessa época para a saída de prata da Espanha, rumo ao Mediterrâneo. Ao contrário, depois de 1570-1575, os testemunhos sôbre êsse tráfico se multiplicam. E êle se trai por suas próprias conseqüências, que são grandes.

Ou muito me engano, ou a substituição da roța Barcelona-Gênova pela rota Laredo-Antuérpia é um dos grandes acontecimentos do século que entāo findava. Todo o grande livro de Ehrenbergh, tāo denso, tão rico de pequenos fatos, em suma, tāo mergulhado no evenementiel, como dizia Simiand, fica esclarecido em seu âmago. As catástrofes de Antuérpia e de Lião, o enigmático declinio de Medina del Campo e de tôdas as cidades ligadas ao circuito nórdico, e, ainda, a ascençāo compensadora dos banqueiros genoveses, a equipagem por elas, a partir de 1579, da grande máquina das feiras de Besançon (estas remontando mais longe no tempo), mas que, a partir de 1579 , embora conservando seu antigo nome, se instalam em Piacenza; tôda essa subversāo da vida econômica e da riqueza da Europa se liga à mudança da porta de 
saída da prata espanhola. O que equivale a dizer também, agora que se sabe pelos trabalhos de Earl Hamilton como a prata americana entrou na Peninsula que é importante determinar para a grande história, quando e por onde ela saiu daí. $O$ qué equivale a dizer também que, além das operações bancárias e de suas hábeis escriturações, o essencial foi a circulaçāo real dos metais preciosos. Verdade que se poderia qualificar de banal se năo fôsse freqüentemente perdida de vista.

E sem dúvida, o problema assim formulado ficaria ainda por resolver. É sintomático ver, senāo se fecharem ao menos se cobrirem de barreiras as grandes rotas oceânicas, no momento exato em que o Mediterrâneo consegue o que nāo é demais chamar de desforra. E nāo menos sintomático é ver o Oceano, pouco a pouco dominado pelas guerras religiosas - essas guerras que velhos hábitos nos fazem situar ùnicamente no continente, nos Países-Baixos a principio, depois na França - ao passo que, no mesmo instante e em sentido inverso, o Mediterrâneo passa da guerra à paz, pois finda, a partir de 1574, o conflito que opõe o Turco ao Espanhol: Guerra no Oceano, paz no Mediterrâneo, pode-se calcular que as conseqüências dêsse duplo fato, mas principalmente a volta do Mediterrâneo à uma vida pacífica, num momento em que a prata da América aflui à sua economia, nāo sāo despreziveis. Isso provocou uma alta de preços mais generalizada e mais rápida que no passado. E assim se preparou uma volta geral à prosperidade, à à fôrça, à vitalidade dos paises mediterrânicos. Veículo: a moeda da Espanha. Desde logo, ela inunda todos os países marginais do grande lago mediterrâneo. Especialmente o escudo de ouro, criado por Carlos V em 1537 (moeda nominal por vêzes, mas mais freqüentemente moeda real) e a peça de prata de ocho reales. Em Tunes como em Argel, como na Turquia, é em moeda da Espanha que se estipulam os montantes das somas a serem pagas pelo resgate de escravos. Assim também, para citar apenas alguns exemplos típicos, em 1581, a 7 de fevereiro, quando o govêrno espanhol concluiu com o Sultāo uma trégua de três anos, por intermédio de Giovanni Margliani - o Marglian das crônicas francesas - os pagamentos dos "presentes" sāo feitos em boa prata da Espanha, em escudos "cunho de Aragāo", segundo afirma uma correspondência francesa. Em Ragusa, não é hábito dọs grandes comerciantes irem êles mesmos ao Levante: êles ai se fazem representar por um filho, um associado, um comissário, o qual, ao partir, leva consigo como única mercadoria uma bolsa bem fornida. Ora, o conteúdo dessa bolsa constitui por vêzes objeto de minucioso inventário, peça por peça, e alguns dêsses inventários foram trans- 
critos nos registros dos Diversa de Foris, no palácio dos Rectores. Êles nos dāo ocasiāo de vermos passar, com o fim do século, as peças espanholas de oito, misturadas a outras moedas (assim. uma vez, aos soltarini de Alepo). Último exemplo: um relato inglês de 1564 assinalava os reais da Espanha como moeda corrente em Alexandria do Egito e como a melhor que para ai se poderia levar. O fato é pois, inegável: todo o Mediterrâneo é entāo tributário da moeda espanhola.

Por outro lado, se a atividade dos banqueiros genoveses - 0 século XVI é desde então o século dêles e nāo mais o dos Függer - pôde-se manter, de maneira próspera, até as alturas de 1640 , nāo obstante as bancarrotas sucessivas e, por assim dizer, regulares, do Estado espanhol: 1596, 1607, 1627, 1647, nāo é sómente, como o disse Ehrenberg, devido à sua habilidade, às' suas gorgetas distribuidas de maneira oportuna, ou como pretendiam seus rivais da Alemanha meridional, porque negociam muito mais com papel do que com dinheiro corrente. Sem dúvida a palavra "bancarrota" pode induzir a êrro; tratava-se muito mais de conversăo de dividas que de verdadeiras bancarrotas. Para se evadir a compromissos muito pesados, o govêrno espanhol, reembolsava seus credores, cada uma das vêzes a prazo curto com juros, isto é, com rendas perpétuas em títulos do Estado, consistindo seu grande lucro em fazer com que se aceitassem essas rendas ao par, pois que sob Felipe II, estavam elas mais ou menos constantemente desvalorizadas de 50\%. Pagos com tais títulos os genoveses deveriam ter sido paralisados em seus negócios. Mas tinham o recurso de pagar na mesma moeda os seus próprios credores - e foi uma vantagem a que jamais renunciaram. Desde 1575, os genoveses da Espanha aproveitaramse dessa situaçāo para arranjar seus negócios, em detrimento dos genoveses de Gênova. Reconheçamos, entretanto, que êsses meios nāo teriam bastado. $O$ que salva os banqueiros genoveses na sua perigosa e especulativa indústria, não é nem sua habilidade, nem a arbitragem que exercem através cle suas feiras, no movimento geral dos capitais na Europa; é que em procissões regulares, nāo obstante a pirataria inglêsa e holandesa, os galeões carregados de prata, formados em longos comboios, apenas excepcionalmente são detidos na sua travessia do Atlântico e chegam até os cais de Sevilha. Há grandes alarmes, retardamentos inverossimeis, dificuldades sem número e surpresas. Mas a ligaçāo se mantem. Dela tudo ciependeu.

Os magnifícos trabalhos de Earl J. Hamilton estabeleceram que o metal branco da América só cessa de chegar maciçamente à Espanha (acrescentemos de nossa parte, além da Espanha, ao Mediterrâneo) pelas alturas de 1640 e 1650 . É, pois, sempre possivel aos banqueiros genoveses continuar seu jôgo especulativo. Jôgo rendoso, pois consiste em tudo e por tudo em fazer através da Europa, por conta do Rei Católico, os pagamentos exigidos pela poli- 
tica universal da Espanha; e fazê-los não sem lucro, mas tendo sempre a perspectiva de serem reembolsados finalmente, em moeda corrente. Sòmente o têrmo da chegada dos galeões da prata terá significado o fim irremediável de Gênova. E a nāo menos irremediável liquidaçīo de suas feiras internacionais. Que belo livro se poderia escrever, além do Zeitalter der Függer de Richard EhrenDerg, sôbre aquêle século que êle, por seu lado, viu mal; época que se səgue a dos Függer, o século dos grandes banqueiros genoveses, árbitros também êles, a seu tempo, dos destinos do mundo e obreiros da grande história! Mas seu reinado, a maneira pela qual transportam de Besançon a Poligny, depois a Chambéry, a Yvres, a Asti e finalmente a Piacenza, a sede de suas feiras e com ela o centro financeiro do mundo, êsse deslisamento para o sul, nāo é uma desforra do Mediterrianeo? E a decadência daqueles nāo é a sua decadência? Nāo está o Mediterrâneo, pelas mesmas razões que Gênova ligado à prata da América?

Em todo caso, é curioso notar que a decadência do Mediterrâneo, tāo logo assinalada por historiadores de boa fé (que frequientemente só tem uma desculpa, a de repetir seus predecessores) nāo se manifestou deveras antes dos meados do século XVII. $\hat{\mathrm{E}}$ pelas vizinhanças dêsse término, marcado pelas realidades da história dos metais preciosos, que se pode falar de uma decadência da Espanha (pensemos na revolta da Catalunha em 1640, na revolta de Portugal, mais grave ainda pois foi definitiva, nesse mesmo ano de 1640). Da mesma forma pode-se desde logo falar de uma decadência da Itália, até mesmo de uma decadência do Império Otomano - mundo mais próximo, é certo, da economia natural e, consequientemente, mais resistente que os países complicados e enriquecidos do Oeste Mediterrâneo. Pode-se também falar de uma decadência do comércio do Levante. É comum dizer-se qué, os holandeses, senhores do Oceano Índico, sāo os responsáveis por isso. Sem dúvida. Mas e a falta de metais preciosos?

Decadência do Mediterrâneo? Sim. Mas além disso, mais do que se pensa, decadência e constrangimento da Europa inteira. Earl J. Hamilton pensa que a América colonial, povoando-se, provendo-se, absorveu quantidades cada vez maiores de numerário. Pensa igualmente que as minas pouco a pouco se esgotaram, que sua exploraçāo, o transporte do metal, com o tempo se tornaram assaz onerosos - a fraude e a incúria governamental agravaram a situaçāo - enfim, que uma parte do metal branco americano desertou pouco a pouco o Atlantico e ganhou o Pacifico pela frota que parte do pôrto "mexicano" de Acalpuco com destino a Manila, onde os juncos chineses vāo buscá-lo. Hipóteses, sem dúvida; mas é fato que as fontes de prata americana secaram, que em 1647 . o govêrno espanhol suprimiu sua frota de barlavento, à entrada do mar das Antilhas, pois a guarda dêste mar se tornara inútil. Repitâmo-lo, nāo é sòmente o Mediterrâneo que se vê condenado a um 
destino menos brilhante. E resto da Europa. Ao século dos genoveses (1550-1630)) vai suceder o século de Colbert, que não é um século de prosperidade.

Esta voltará. E uma vez mais, em parte, graças à América. Longa história, que nos desculpamos de abordá-la assim, numa palavra, a título de exemplo análogo e assim o fazemos em memória de Marc Bloch, que para isso chamava atençāo nos últimos anos de seu professorado. Desde o fim do reinado de Luiz XV, nāo assinalara êle uma volta à prosperidade ou pelo menos, as primícias dessa volta? Nāo podemos ver nisso uma nova dádiva da América para Europa, um dom agora não mais de prata, mas de ouro de Minas Gerais, tirado do próprio coraçāo, do coraçāo continental do Brasil? Ouro - e é justamente nos últimos anos do século XVII que êle aparece. Não vamos por certo dizer que foi êle, só êle que determinou o século XVIII. Mas diremos, uma vez mais, que as vicissitudes da moeda não interessâm apenas à história econômica. Elas contribuem poderosamente para esclarecer a história total das sociedades e das civilizações. Valem como signos. Valem como causa.

Resumamos. Primeiros anos do século XVI: o ouro do Sudão já desviado pelos portuguêses de seu caminho direto para o Mediterrâneo, desemboca em novas rotas, em direçăo ao Oceano Îndico. E, como por acaso, a primeira Renasceça Italiana se estiola, periclita e empalidece

Trinta anos: eis que afluem para a Europa os metais da Amésica, retransmitidos por Sevilha. Como por acaso, igualmente, o poderio espanhol se afirma e se expande. Os genoveses contribuem para isso, pois desde o comêço tomaram posiçāo contra os portuguêses, e logo suplantam os banqueiros de Augsburgo. Mas, por outro lado, se o Mediterrâneo se beneficia com a prata espanhola, nem sempre a recebe diretamente. A grande via por onde o maná se derrama é a via oceânica. A via de Laredo a Antuérpia. Por ai nāo cessam de correr as ondas de um Pactolo que rega ao mesmo tempo a aridês da Espanha e as terras férteis das Flandres.

Até o dia em que esta via é cortada; em que Antuérpia conseqüientemente começa a murchar; em que Medina del Campo se estiola, em que Liāo deixa de ser a cidade triunfal das feiras; em que a Espanha se vê cortada das Flandres por mar, mas, em que, ao contrário, a rota maritima de Barcelona a Gênova ganha vigor, em que as moedas da Espanha conquistam inteiramente o Mediterrâneo, e prolongam. sua prosperidade até os meados do sécuio XVII... Até a hora em que (talvez drenado para Manila, talvez absorvido pela própria América em progresso) o metal branco deixa de inundar o Mediterrâneo e, conseqüentemente, a Europa. Declínio, decadência, que só será remediada às vésperas do sécu- 
lo XVIII. por um afluxo novo de riqueza amoedada. Por um afluxo de ouro: o das minas brasileiras, das "Minas Gerais".

Assim se cadenciam os capitulos da história do mundo. No ritmo des fabulosos metais.

\section{FERNAND BRAUDEL}

Professor do Colégio de França e exprofessor da Faculdade de Filosofia, Ciências e Letras da Universidade de São Paulo. 